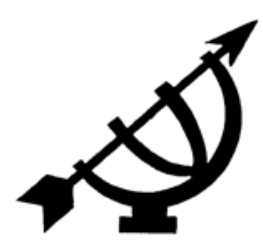

\title{
A critique of social marketing in the non- profit development sector
}

\author{
L.M. Fourie \& J.D. Froneman \\ School of Communication Studies \\ Potchefstroom Campus \\ North-West University \\ POTCHEFSTROOM \\ E-mail: Lynnette.Fourie@nwu.ac.za \\ JD.Froneman@nwu.ac.za
}

\section{Abstract \\ A critique of social marketing in the non-profit development
sector}

In its struggle to find funding, non-profit organisations worldwide are increasingly using social marketing strategies. This approach potentially influences non governmental organisations (NGOs) and community based organisations (CBOs) in their communication with their "clients", i.e. those persons and communities in need of development. Marketing strategies consequently become instruments in achieving social development, with as main premise that behaviour could be changed by means of persuasive, top-down communication.

Social marketing, with its roots in marketing, has a strong focus on persuasion and favours top-down communication rather than dialogical communication strategies suggested by the participatory development communication approach. It is also questionable whether social marketing can be equated with the principles of a Biblically informed approach to communication. With these questions in mind, this article discusses Biblical views on communication and the participatory development communication approach. A critique of the social marketing approach is then offered.

It is argued here that there is no clear-cut answer as to whether social marketing could be described as participatory. What is clear is that there are many different views on social marketing, as is the case with participatory approaches. It would thus seem more correct to place social marketing on a participation con- 
tinuum, rather than to define it as being participatory and thus per definition ethical or not. Finally, a number of suggestions are made which could bring it more in line with the participatory communication approach as well as Biblical principles on communication.

\section{Opsomming}

\section{'n Kritiese beskouing van die sosiale bemarking in die nie- winsgewende sektor}

Nie-winsgewende organisasies (NWOs) gebruik toenemend sosiale bemarkingstrategieë in hulle soeke na fondse. Hierdie benadering kan potensieel ook nie-regeringsorganisasies (NROs) se gemeenskapsgebaseerde organisasies (GBOs) se kommunikasie met hulle "kliënte" (persone en gemeenskappe wat ontwikkeling nodig het) beïnvloed. Die gevolg is dat bemarkingstrategieë 'n instrument vir sosiale verandering word. Die hoofaanname wat gemaak word, is dat gedrag verander kan word deur middel van oorredende eenrigtingkommunikasie.

Sosiale bemarking, met sy wortels in bemarking, het 'n sterk fokus op oorreding en gee voorkeur aan eenrigtingkommunikasie, eerder as dialogiese kommunikasiestrategieë soos deur die deelnemende benadering tot ontwikkelingskommunikasie voorgestaan word. Dit kan ook bevraagteken word of sosiale bemarking voldoen aan die riglyne van Bybels-gefundeerde kommunikasie. Teen die agtergrond van hierdie vrae word Bybelse perspektiewe op kommunikasie en die deelnemende benadering tot ontwikkelingskommunikasie in hierdie artikel bespreek. Daarna word kritiek gelewer op sosiale bemarking as kommunikasiebenadering.

Daar word geargumenteer dat 'n klinkklare antwoord op die vraag of sosiale bemarking as deelnemend beskryf kan word, nie gegee kan word nie. Wat egter duidelik is, is dat daar 'n verskeidenheid standpunte is oor wat sosiale bemarking presies is, soos ook in die geval van die deelnemende benadering. Dit blyk dus meer korrek te wees om sosiale bemarking op 'n kontinuum van deelname te plaas, eerder as om dit te probeer definieer as deelnemend (en eties) al dan nie. In die laaste instansie word voorstelle gemaak wat sosiale bemarking meer deelnemend sal maak en derhalwe ook meer in ooreenstemming met Bybelse riglyne vir kommunikasie.

\section{Introduction}

In its struggle to find funding, non-profit organisations world-wide are increasingly using social marketing strategies. This approach potentially influences NGOs and CBOs in their communication with their 
"clients", i.e. those persons and communities in need of development. Marketing strategies consequently become instruments in achieving social development, with as main premise that behaviour could be changed by means of persuasive, top-down communication.

Those preferring the participatory communication approach, find the top-down approach a clear fallback to the now discredited modernist approach. Given the fundamentals of the marketing approach, it raises pertinent ethical questions about the nature of the communication employed by marketing influenced organisations. Some of these questions are informed by the participatory approach (with its strong emphasis on dialogical communication). More fundamentally, one can also question some of the marketing approach's points of departure from a Christian perspective on communication. As some of the organisations employing marketing methods in their development work are Christian-based organisations, a critique of its (marketing orientated) approach is important.

Participatory communication is currently the pre-eminent normative approach when engaging with developing communities. Despite ambiguities regarding what participation exactly entails as well as practical problems in the implementation of this approach, it is widely accepted that participatory development communication is more sustainable than its predecessor, the modernisation approach, had been. More importantly, the participatory approach seems more in line with basic fundamentals of a Christian approach to communication and development.

With this in mind, this article intends a critique of the social marketing approach. We will also make a number of suggestions regarding the social marketing approach, which could bring it more in line with the participatory communication approach with its strong emphasis on dialogical communication. Consequently, the social marketing approach may well be brought much closer to Biblical points of departure suggested here.

In order to set the scene for a critique of the social marketing approach, we will first discuss some points of departure regarding a Biblical approach to communication, followed by a brief overview of how development communication evolved. 


\section{Some Biblical principles regarding communication}

Veenstra (1994:81-82) postulates three principles regarding ethical (read: Biblically informed) communication. The first is the overarching sovereignty of God. As Creator God gave us the ability to communicate with Him and "enter into relationships with people". We are because we communicate. This implies respect for communication and the need to communicate ethically. Veenstra (1994:81) stresses that we should "attempt to promote understanding and practice of communication" in order to "show respect for people".

The second basic principle refers to the idea that a person "is a directional creature; communication influences the direction of a person's life. Thus the (ethical) question should be posed repeatedly: How am I influencing this person? What will the long-term result of my communication with this person be? And am I helping this person to live more obediently before God? Thus all communication, Veenstra (1994:82) states, "has a moral dimension - the dimension of direction for God or against God".

The third basic principle suggested by Veenstra (1994:82) relates to the need to give full respect to all persons. This respect is based on the view that a person is a created being who carries some likeness to God. The other person is an intellectual and moral being - "one who is able to consider information and make choices". We are all called to be God's representatives and thus rule in his place.

Veenstra suggests a number of sub-principles that link the abovementioned principles in a very direct way to the theoretically points of view that constitute participatory approaches to development communication. They include "honesty, correct attitudes towards others, respect for a person's intellect; and an attempt to satisfy others' needs" (Veenstra, 1994:82).

Snyman (1994:49) makes very much the same point when he describes the essence of ethical behaviour as:

Those actions of people (as expressions of their full humanity) which are of the kind that promote a person's well-being, which do what they ought to do, namely recognize, respect, and promote the person(hood) of themselves or the other ...

Elsewhere Snyman (1983:857, 858; cf. also 864-867) argues that "propaganda" (i.e. propagating a particular point of view) is potentially enslaving and undermining of human interests. This implies the opposite of a loving caring-for-the-other. 
Especially relevant to participatory development communication is an important statement of principles by the World Association of Christian Communicators (WACC) (2009) which states, inter alia:

Only if people become subjects rather than objects of communication can they develop their full potential as individuals and groups. Communication is now considered an individual and social necessity of such fundamental importance that it is seen as a universal human right. Communication as a human right encompasses the traditional freedoms: of expression, of the right to seek, receive and impart information. But it adds to these freedoms, both for individuals and society, a new concept, namely that of access, participation and two-way flow.

Participatory communication may challenge the authoritarian structures in society, in the churches and in the media, while democratizing new areas of life. It may also challenge some of the 'professional rules' of the media, whereby the powerful, rich and glamorous occupy centre stage to the exclusion of ordinary men, women and children. Participatory communication, finally, can give people a new sense of human dignity, a new experience of community, and the enjoyment of a fuller life.

The mass media are a form of power and often part of a system of power. They are usually structured in such a way as to reinforce the status quo in favour of the economically and politically powerful. Mass media power thus has a dominating effect which is contrary to genuine communication.

We cannot communicate with people whom we regard as 'inferior', whose basic worth as humans we do not respect. We can simply impart information to them or sell 'media products' to them. Genuine communication presupposes the recognition that all human beings are of equal worth. The more explicit equality becomes in human interaction, the more easily communication occurs.

Communication which liberates, enables people to articulate their own needs and helps them to act together to meet those needs. It enhances their sense of dignity and underlines their right to full participation in the life of society. It aims to bring about structures in society which are more just, more egalitarian and more conducive to the fulfilment of human rights.

And on a very practical level, the following pointers to positive, fruitful communication is suggested by SimplyBible.com (2009): 
- Truth in love: "Speaking the truth in love, we are to grow ..." (Eph. 4:15). Using these two criteria alone, we can eliminate just about all evil and negative communication. Is what we say truthful, and is it spoken in love?

- Let Yes be Yes: Jesus says, "Let your yes be yes, and your no be no" (Matt. 5:37). It is up to us to say things that ought to be trusted, and to say those things simply. The trust is up to others. People will begin to trust us when they find our word to be consistently reliable.

- Be slow to speak: "Quick to hear and slow to speak" (Jas. 1:19). This does not mean that we take ages to say anything. Rather, it means that we think before we speak, and that we listen to others before we answer them, so that our reply will satisfy their needs.

- The name of Jesus: "Whatever you do, in word or deed, do all in the name of the Lord Jesus" (Col 3:17). If we ensured that what we say is what Jesus would say, and when we speak we represent God properly, that would eliminate all negative and destructive communication. Peter said the same thing in another way, and this is a fitting statement with which to close our lesson: "If any man speak, let him speak as if it were the oracles of God" (1 Pet. 4:11).

These thoughts will be utilised to eventually provide a normative critique of social marketing and guide our suggestions vis-à-vis a social marketing approach more in line with participatory development communication.

\section{Development communication: from modernisation to participation}

Modernisation, with its roots mainly in economic and social evolutionary theory, was the dominant paradigm for addressing development issues in the fifties and sixties (Melkote, 2002:421). The work of Schramm (1954) and Lerner (1964) emphasising the importance of the mass media in the developmental process, contributed to the advancement of communication campaigns aimed at development in the 1960s. Modernisation theorists believed that communication was the impetus for change; simply stated, they argued that by exposing people to new ideas, change (and by implication, development) would take place. The linear approach of modernisation made it especially appropriate to apply to communication campaigns. 
During the 1960s developmental campaigns, especially regarding family planning, agriculture outreach, et cetera, became popular, but the outcomes were disappointing (Snyder, 2002:458). From the 1970 s the modernisation approach was criticised, especially by scholars from Latin America and Asia. The main criticisms were that modernisation was viewed from a Northern perspective. These countries provided the blueprint according to which the developing countries were supposed to develop (cf. Melkote, 2002:422; 2004; Huesca, 2002:500; Waisbord, 2001:17-18). Participatory approaches to development communication resulted from this criticism.

\section{Development communication: focus on the dialogical approach}

Various views exist on what participation exactly means and how it should be applied. When these viewpoints are summarised it seems that the main aim of the participatory approach is to be more democratic and to empower the community (Jacobson, 2003:87; Snyder, 2002:463). Empowerment through dialogical communication and a focus on different cultural situations are thus fundamental to the participation approach. The dialogical approach is thus central in this discourse. The philosophical grounding of the concept empowerment draws on the work of Paulo Freire. In his Pedagogy of the oppressed, Freire (1970) criticised one-way communication in education and advocated a more interactive approach which would raise the learners' consciousness. This approach was based on praxis, enabling people to serve as their own examples in developmental efforts. This implied that the distance between teacher and student and, in the case of development, the developmental agent and client should disappear to form a co-learning experience, based on the praxis of action and reflection.

The disappearance of an object-subject relationship combined with critical reflection resulted in a heightened moral awareness or conscientizacao (Huesca, 2002:502; Waisbord, 2001:19; Barranquero, 2005:920-925). The concept empowerment entails not only an emotional or motivational dimension, but also a cognitive or intellectual dimension. It includes an understanding of social circumstances that lead to the disadvantaged position (Rogers \& Singhal, 2003; Melkote, 2004). The goal of participation should be to facilitate conscientization as this is how communities realise their problems and needs, and importantly, identify the constraints to address these problems (Melkote, 2002:428; Thomas, 1994:50-52; Barranquero, 2005:921). This would be comparable with the WACC principle that 
communication liberates and enables people to articulate their own needs and enhances their dignity by exposing them to new ideas.

Empowerment supposes a transfer of power. This implies that a community assumes control of its own situation; the community must thus be empowered to help itself. Empowerment requires more than information delivery; it requires the community to actively reflect on the message (Melkote, 2004).

Dialogue is thus more than the mere exchange of information, but requires moral commitment and is not imposing or manipulating (Huesca, 2002:502; 1996:528).

Dialogical communication affords a person an opportunity to discover truth by means of conversation. The assumption regarding true dialogue is that both parties are presented with all relevant information and not manipulated. This clearly correlates with the key concepts of truth, respect, freedom to choose, two-way communication, et cetera mentioned in the section on Biblical principles regarding communication.

\section{Participatory development communication: some criticism}

The participatory approach could presently be regarded as the preeminent approach to address developmental issues (cf. Huesca, 2002:499; Melkote, 2002:426-427). However, the approach is not without problems and criticisms of its own, mainly pertaining to the definition of participation and its practical implementation (cf. Waisbord, 2001:21; Melkote, 2002:428; Huesca, 2002:499; Jacobson, 2003:87-88; Cleaver, 2001:786).

Critics of the participatory approach feel that it is idealistic to implement a participatory approach, especially where funding and, therefore, concrete results are needed. It is often frustrating and impractical to design and implement a campaign that is participatory when faster top-down approaches seem more effective in the short term (cf. Waisbord, 2001:21-22; Cleaver, 2001:792).

A further aspect that leads to queries is whether participation should be employed at all stages of program development and implementation. In practice, participation is often only applied at the implementation stage. Although this could be questioned from a normative perspective, Waisbord (2001:21) argues that participation in all stages does not have the same relevance. As indicated by 
Fraser and Restrepo-Estrade (1988:577-578) development communication has three different, but related, functions. Social communication occurs in the community and promotes dialogue helping people to gain insight into their needs and to find possible solutions to their problems. Educational communication aims to provide the knowledge people need to change. Institutional communication refers to the communication between all the partners involved in a development project.

Another question is whether participation has to be individual (as the dialogical approach would suggest), or whether participation could be seen as functioning through representatives and/or a committee system (Cleaver, 2001:791).

The critique against the participatory approach mainly refers to practical issues, and not normative questions. It seems that communication practitioners working in the field of social development agree that participation is necessary for sustainable development, but that they differ in their definitions and applications. It is therefore not surprising that participation has been defined in many different guises, ranging from the participation-as-a-means approach to the participation-as-an-ends approach. The former is very much a repackaging of modernisation approaches, while proponents of participation-as-a-means generally see participation as a basic human right, regardless of the outcome.

Against this background, protagonists on behalf of social marketing argue that social marketing could also be participatory, i.e. consistent with the Christian perspectives discussed earlier. The concept of participation is thus not at stake, but the way in which it is used.

\section{Social marketing: its roots and definition}

Social marketing came to the fore in the early 1970 s and gained impetus as a result, among other reasons, of funding from USAID and the World Bank and became popular, especially in the field of health communication (Snyder, 2002:457-459; Melkote, 2002:419-420; Fraser \& Restrepo-Estrade, 1988:572).

Although social marketing shows a resemblance to modernisation it did not actually develop directly from the dominant paradigm, but rather from marketing theory (Melkote, 2002; Snyder, 2002; Waisbord, 2001). The dominant focuses in marketing theory also influenced the conceptualisation of social marketing, reflecting a move 
from top-down persuasive communication to a perspective focusing more on the consumer and on consumer relationships. As in the case with participatory development communication, there are also different views on what social marketing exactly entails.

The first definitions of social marketing emphasised the importance of communicating the message and the selling of ideas (cf. Domegan, 2008:135-141). Kotler and Zaltman's (1971:5) definition is generally accepted as the first formal definition of social marketing:

... the design, implementation and control of programs calculated to influence the acceptability of social ideas and involving considerations of product planning, pricing, communication, distribution and marketing research.

This focus on communication meant that social marketing was often equated with information dissemination or with the changing of attitudes in the hope that this would lead to behaviour change in the long run. Later it was argued that social marketing is a much broader concept including attitudes and behaviour and could only be effective if all the components of the marketing mix were included and correctly applied (Bloom \& Novelli, 1981:79; Andreasen, 1994: 112; Smith, 2006:i38-i43; Rayner, 2007:195-199; Fox \& Kotler, 1980:25-26).

Against this background, Andresaen (1994:109-111) developed a more comprehensive definition of social marketing, namely:

... the adaptation of commercial marketing technologies to programs designed to influence the voluntary behaviour of target audiences to improve their personal welfare and that of the society they are a part of ...

The key elements of social marketing could thus be summarised as influencing behaviour by using a systematic planning process, applying traditional marketing principles and techniques with the aim of benefiting society by resolving certain social issues (Kotler \& Lee, 2008:8; Brenkert, 2001). The influencing of behaviour could entail manipulation of the receivers without all the facts being presented, an approach which is clearly not consistent with Biblical principles on communication.

Although the focus in this article is on the non-profit sector, it should be noted that social marketing is not limited to the non-profit sector; nor is all non-profit marketing social marketing (Fox \& Kotler, 1980:25; Smith, 2001:1-16; Brenkert, 2001). 
The ethics of social marketing per se cannot be questioned and the issue is not whether social marketing has the greater good in mind. Neither should the effectiveness of social marketing be questioned. There are ample examples of success stories (cf. Waisbord, 2001:8). It should, however, be noted that the bulk of these examples are taken from the developed world and relate to issues of smoking, alcohol abuse, drug abuse, the use of seatbelts, et cetera. These issues are by no means unimportant, but they are not as complex and intertwined with social factors as is typical in the case of developmental issues such as HIV and AIDS.

What is questioned here, is the way these successes are achieved. In other words, applying traditional marketing principles and techniques in a developmental context is at issue here. This is done by evaluating the following key issues: behaviour, exchange, customer, product, price, place and promotion against the principles of Biblical communication and the dialogical approach to development communication.

\section{Key concepts in social marketing}

\subsection{Behaviour}

The bottom line of social marketing is behavioural change. Social marketers thus evaluate the success of a campaign in terms of behavioural change and not in terms of awareness or attitudinal change (Andreasen; 1994:108-110; Smith, 2006:i39; MacFadyen et al., 1999).

Furthermore, behavioural change is voluntary (Andreasen, 1994: 111; Stead et al., 2007:189; Brown, 2006:384-387) and does not necessarily involve the adoption of new behaviour, but could actually discourage behaviour such as the abuse of drugs (Andreasen, 1994:111). Voluntary behavioural change is achieved through an exchange of values, not because people are well-informed or are forced, but because they receive something in return (Smith, 2006:i39; MacFadyen et al., 1999).

As behavioural change distinguishes social marketing from educational and persuasive communication, behavioural change also indicates when the use of social marketing is appropriate. Andreasen (1994:111) illustrates this by using the example of trying to persuade a woman who does not understand the notion of contraception to engage in family planning. This would be contrary to the views of Veenstra, Snyman and (particularly) the WACC, which requires an 
individual to fully understand and participate in a given situation without being forced and treated without full dignity.

Andreasen (1994:112) and Cortès (1997:582) make the very important point that social marketers should not try to undertake basic education or value change if this seems challenging and a long term option. Although social marketing does include education and value change, it should not be the method of choice where dramatic value change is required or if the desired behaviour conflicts with the dominant values of the target audience. Duhaime et al. (1985) emphasise that social marketing can only contribute to development within a favourable social, economic and cultural framework. Social marketing is thus not necessarily the best (or only) method when developmental issues are at stake.

One of the major criticisms against the now largely discredited modernisation approach is the focus on the individual as the locus of change. Social marketing also tends to see behaviour as largely the responsibility of the individual rather than of society as a whole, thus ignoring trends in society that could influence the desired behaviour change (Rayner, 2007:195-199). Participatory development communication approaches behavioural change in a more holistic fashion, taking environmental constraints into account.

This, however, does not suggest that social marketing could not also take a broader approach. More problematic is the notion that behavioural change is induced by means of an exchange.

\subsection{Exchange}

The concept of exchange has its roots in marketing theory and is central to economics. While economists tend to focus on exchange itself, marketers focus on the dual concepts of profit and customer satisfaction (Peattie \& Peattie, 2003:368; Kotler \& Lee, 2008:14; MacFadyen et al., 1999). Likewise, social marketers work from the premise that behaviour change will occur if there is a clear benefit for the "customer" (Stead et al., 2007:189; MacFadyen et al., 1999).

However, if the concepts of profit and customer satisfaction are applied to the domain of social marketing there are some areas of concern. First, social marketing campaigns are not necessarily aimed at customer satisfaction (although they could lead to satisfaction), but rather at improving social welfare, safety, risk reduction and the avoidance of dissatisfaction (Peattie \& Peattie, 2003:368). Furthermore, social marketing sometimes has unintended effects 
that also need to be considered (Smith, 2006). This implies that not only individuals, but society as a whole, could be affected and that all parties affected should be taken into consideration (Brenkert, 2002:16; Rayner, 2007).

Second, social marketing campaigns rarely aim to show a profit, but rather to reduce costs by resolving social problems (Peattie \& Peattie, 2003:368; Brenkert , 2002:15; Kotler \& Lee, 2008:13).

There are several concerns to bear in mind when applying exchange theory to social marketing in a developmental context. This includes that exchange in social marketing is more complex and (ambiguous) than in commercial marketing. It is more difficult to "sell" benefits that a consumer may never see, such as not getting cancer or HIV (Hastings \& Saren, 2003:309-310; Brenkert, 2002:17). In commercial marketing goods are exchanged for money; in social marketing it is a symbolic exchange of psychological, social or other intangible entities (Brenkert, 2002:17). In the case of market exchange, an individual has a choice as whether to engage in the exchange or not. In the case of social marketing, the "consumer" is often affected by the change without having a choice.

Another concern is that the benefactor might want to benefit from the exchange. As Hastings and Saren (2003:310) note, it is the notion that people are self-seeking that makes the consumer orientation so powerful. In other words, the best way for me to get what I want, is to persuade you that what I am offering in exchange is in your best interest. However, in the development context the beneficiary should not be the social marketing organisation as is the case with commercial marketing (Andreasen, 1994:112; Stead et al., 2007:190-193; Brenkert, 2002:20). In practice, however, developmental projects are often shaped by what the donor wants.

The concept of exchange implies some type of relationship between social marketer and customer. The nature of this relationship we regard as problematic. Relationship management theory distinguishes between a communal and an exchange relationship. An exchange relationship implies that one party maintains the relationship in exchange for certain behaviour by the other party. As the social marketer usually has more power than the community it seeks to change (Brenkert, 2001:46; Hastings \& Saren, 2003:310), the relationship often takes the form of an exchange relationship. Keeping the principle that you cannot communicate, but merely disseminate information with people whom you regard as inferior in mind (WACC, 2009), a focus on exchange relationships when develop- 
mental issues are at stake, raises a concern. The nature of exchange relationships clearly contradicts the basic assumptions of dialogical communication and Biblical principles.

In a communal relationship both parties are willing to provide benefits to the other, because they are genuinely concerned for the welfare of the other - even when they believe they might not receive anything in return. Although exchange relationships are necessary and, in many instances, a relationship starts as an exchange relationship and develops into a communal relationship, research has indicated that long term quality relationships and especially trust are maintained by fostering communal relationships (Grunig \& Hon, 1999:21). Development communication practice has shown that development has been more sustainable where longterm relationships and high levels of trust are established. This would also be in line with the Biblical principles outlined earlier in the article.

Some researchers (cf. Smith, 2006; Hastings \& Saren, 2003:309; MacFadyen et al., 1999) within the field of social marketing have taken these criticisms to heart and argue that the exchange must be mutually beneficial. Effective behavioural change often involves compromise, implying that social marketers should alter their offerings to suit the target audience. The focus is thus on the audience and not the marketer. However, Hastings and Saren (2003:311-312) admit that relationship marketing is concerned with influencing (even manipulating) consumer demand.

Peattie and Peattie (2003:370) built on the concept of relationships and argue that exchange is not a defining characteristic of social marketing. Rather, they emphasise the importance of interaction. If exchange is involved, it often takes the form of conversation or the sharing of beliefs that may later lead to changes in beliefs. This, however, is not the same meaning economists and especially marketers assign to the concept of exchange.

If exchange is defined as interaction, it would be in line with the principles of participatory communication and the WACC (2009) principles that state that communication should enable people to be able to articulate their own needs and then help them to achieve these needs.

The exchange would then not be a transaction were one party changes behaviour in order to receive a benefit. It would rather assume the form of a communal relationship, where both parties work towards a common goal. The needs of the community as well 
as the desired behavioural change could then be negotiated by both parties. This would ensure that contextual factors as well as indigenous knowledge are incorporated in the proposed behaviour change, which would also be in line with the Biblical perspectives on communication stated above, especially Veenstra's (1994:82) third principle stating that all people are intellectual beings that are able to consider information and make choices.

\subsection{The consumer orientation}

Whereas participatory communication views the community as central in the process of development, social marketing is consumer orientated. The consumer approach, as described by MacFadyen et al. (1999), is indeed very participatory. They see the consumer as an active participant in the changing process and aim to build long term relationships with the customer. It could be summarised as follows: not asking what is wrong with these people, why won't they understand, but what is wrong with us, what don't we understand about our target audience? Furthermore, the consumer or community also has something to contribute to the process of product development (Glenane-Antoniadis et al., 2003; Hastings \& Saren; 2003:305-322; Waisbord, 2001:10). This viewpoint takes the basic assumptions into account of both the dialogical approach to development communication, as well as the Biblical guidelines to development communication as stated previously.

On the other hand, some authors (cf. Brenkert, 2002:17; Smith, 2006:i38-i43; Cortès, 1997:580) warn that social marketers usually know what they want to achieve before they start a campaign. Thus, they do not analyse the target audience to determine their needs. Instead, they decide how to "package" the message in order to obtain the desired behavioural change. This approach clearly resembles modernisation thinking. It also highlights one of the central problems of participatory communication, namely that there are certain practices that ensure a healthy lifestyle, no matter what the needs and preferences of the community (Fraser \& RestrepoEstrade, 1988:572-578). Veentra (1994:81) also touches on this problem when stating that all communication is "directional" and thus has an influence on a person's life. For him the ethical question is whether the communication is directed for or against God.

To analyse the audience in order to be able to persuade individuals to buy a product is common within commercial marketing practices. However, the consumer (or audience) of the social marketer differs considerably from that of the commercial marketers. This raises 
some questions about the applicability and ethics of the consumer approach.

For the commercial marketer, the consumer tends to be one individual or organisation, while in social marketing the consumer is a group, for example the community, wider society or the general public (Glenane-Antoniadis et al., 2003:329-303; Brenkert, 2001). The implication is that the desires of these groups could be in conflict. For example, a smoker may be content to smoke (individual satisfaction), but it is not in the best interest of him-/herself or the rest of the family (social welfare).

A second issue is the capacity of the audience. Individuals are not always capable of understanding and accepting advice about a product or service and the consequences of doing so (Smith, 2001:8-9). This is especially a concern as this impedes on a person's ability to make a choice and increases the chances of manipulation.

Although the consumer approach involves the consumer, it is not participatory (or in step with Biblical love) in the true sense of the word. The aim of participation can therefore be questioned and it would seem that social marketers tend to define participation as participation-as-a-means to determine what message will change the consumer's behaviour rather than to determine what the behavioural change should be. This could be acceptable, if, as argued earlier, there are certain practices that ensure a healthy lifestyle and are for the greatest good and the message is directed towards God.

Our concern is at a more fundamental level: should community members indeed be seen as consumers. Rayner (2007:195-199) questions whether behaviour can be consumed and therefore whether a target audience can act as consumers. Whereas a product satisfies a specific need and is consumed in the sense that it wears out and one needs to buy a new one, behaviour cannot wear out.

When the principles of the dialogical approach and the WACC are taken into account, defining the community as consumers needs to be questioned. One of the key assumptions of the dialogical approach is that the distinction between object and subject should disappear to enable a co-learning experience. In this regard the WACC (2009) argues that people need to become subjects (instead of objects) of communication in order for communication to fulfil its potential as universal human right. The distinction between marketer and consumer appears to contradict this notion. 


\subsection{The social marketing mix: product}

The product concept is one of the most difficult to transform from the commercial to the social marketing context. One view is that the product is the end of behavioural change, while another view is that the "tools", such as information, are the products (Smith, 2006:i38i43; Peattie \& Peattie, 2003:371-374).

Peattie and Peattie (2003:371-373) rightly argue that both these views are problematic as the behaviour is not "produced" by the social marketers or their organisation. It is also not owned or transferred by them. Rather, it is the recipient that produces the behavioural change. The social marketer is merely the facilitator. Similarly the components of the campaign cannot be seen as products, since the campaign benefits come from the behavioural change and not from the products in the first place. In line with this argument, Rayner (2007) questions whether exercise can be marketed as a commodity in the same way as, for example, running shoes, since the benefits of physical exercise only become evident in the long run. To address this problem, Peattie and Peattie (2003:371) propose that social marketers offer their target audiences propositions rather than products.

Within the context of participatory development communication the whole concept of offering consumers a product seems problematic as this assumes expert-one-way communication. This also contradicts the Christian notion of the right of choice. When these normative views are taken into account, it might be assumed that the developer and community would develop a mutually beneficial and accepting proposition together.

\subsection{The social marketing mix: price}

Kotler and Lee (2008:8) argue that social marketers sell behaviour whereas commercial marketers sell goods and services. Price is seen as the cost of behavioural change in the context of social marketing.

The cost may be monetary or non-monetary. Monetary costs include nicotine patches, condoms, et cetera. However, especially in a developing society, it is the non-monetary costs that are at the heart of social marketing. These include the time, energy and effort to behave in a certain way, psychological risks and physical discomfort (Kotler \& Lee, 2008:227-229; Bloom \& Noveli, 1981:83). 
Peattie and Peattie (2003:375), however, highlight that price and cost are not the same. Cost is a much more comprehensive concept, especially as it is used in the social marketing context. While financial cost is universally understood, the cost of adopting social behaviour differs in different circumstances and phases of the adoption process. It is therefore impossible to attach a cost to behavioural change (Bloom \& Noveli, 1981:83). This concern is even bigger in a complex developmental context, where the same issues and circumstances are rarely at stake in different programs.

\subsection{The social marketing mix: place}

In commercial marketing, place refers to the physical place of product distribution or service delivery. In terms of social marketing, place refers to accessibility and the locations of the planned interventions. Where physical products are involved, the distribution will be very similar to that of the commercial market. However, it is with regard to accessibility that social marketing differs from commercial marketing (Peattie \& Peattie, 2003; Kotler \& Lee, 2008:247; Smith, 2006:i39).

It is proposed here to refer instead to the context of the developmental program rather than to the place. The context could, for example, imply that the social marketer is not a member of the community to which the social marketing campaign is directed at. The social marketer is probably not from the same culture or ethnic group as the target audience, implying that he/she might not have an understanding of the community and their problems (cf. Brenkert, 2001:45-46).

The context may have a profound impact on a developmental program (Duhaime et al., 1985:9-10; Kelly et al., 2003:411-420). In their model of social marketing for the Third World, Duhaime et al. (1985:3-13) identify enabling conditions which influence development, including political/administrative issues, economical, social, communicational and cultural issues. Kelly et al. (2003) propose a community readiness model to be utilised in conjunction with social marketing. This model provides an additional framework to analyse the audience with the primary aim of determining whether the community would be able to manage the proposed behavioural change. This would underscore both Veentra's and the WACC's argument that people need to understand communication to be able to make a choice. 
When the notion of multiplicity (cf. Servaes, 1999) is taken into account, it is evident that the context can determine the success or failure of a program. In the developmental context, the concept of place thus entails much more than the physical place.

\subsection{The social marketing mix: promotion}

Promotion can be easily translated from the commercial to the social marketing context as it is very similar to commercial marketing. Promotion is primarily a communication strategy designed to persuade the target audience to adopt the desired behaviour (Kotler \& Lee, 2008:268).

This strong resemblance to marketing theory also signals a warning in the developmental context (Peattie \& Peattie, 2003). The persuasive nature of promotion could very easily result in top-down communication and could be seen as manipulation and not as fair treatment dignifying a person's personhood.

\section{Conclusion}

In this article we posed the question whether social marketing could be compatible with (ethical) participatory communication and Christian perspectives on communication. We could not offer a straightforward answer. It is not even clear exactly what is seen as participatory communication as the level of participation varies. It would be more appropriate to speak of a participation continuum, with participation as a means (on one end) and participation as an end (on the other).

Following this line of thinking, social marketing could also be judged on a continuum. From the above discussion it is clear that there is more than one view of what social marketing comprises, and especially of the manner in which it should be implemented.

Social marketing can clearly contribute to social development in the sense that it formalises the communication process and emphasises the importance of strategic communication. However, social marketing is by no means the only (or best) approach in all circumstances. The context and nature of the developmental issues should dictate the approach instead.

The strong link of social marketing to marketing theory remains a concern, especially the concepts of exchange and customer. The notion of exchange implies that the customer changes his/her behaviour in order to receive a benefit. This does not acknowledge 
the principles of the dialogical approach or the WACC's statement (in which the distinction between customer and marketer ought to disappear) and the view that behavioural change should be the result of a mutual decision. It also does not conform to the Biblically informed norm of empowering people to make informed decisions.

The translation of the marketing mix perspective onto the social marketing context is an uncomfortable fit. The emphasis on the total marketing mix is understandable as this ensures an holistic approach. This is one of the strong points of social marketing and is also proposed by the participatory approach. However, as other authors (Peattie \& Peattie, 2003; Kelly et al., 2003; Hastings \& Saren, 2003; Glenane-Antoniadis et al., 2003, Domegan, 2008) have argued, social marketing should look beyond marketing theory for direction. We thus suggest that the marketing mix could be adapted to be more applicable (and normatively acceptable) when used to address developmental issues.

It is especially the notion of the product that needs to be reconsidered. Perhaps the product should be seen as part of a broader product analysis and therefore referred to as a possible/ negotiated solution. As product and place are often intertwined in a developmental context, the place should refer to the contextual factors influencing the possible solutions. If price is viewed within the broader context of cost, it would be more suitable to the developmental context. In this way the emotional "cost" of communities would also be taken into account. This would imply a more ethical approach, as the focus will be on negotiated solutions which would be in line with the principles of a Christian view and the dialogical approach.

Although promotion is the easiest component to apply to social marketing, it is also a concept that needs to be redefined if it is to be suitable for a participatory approach informed by Biblical principles. It would be more appropriate to refer to communication and to acknowledge the two-way nature of ethical communication.

It is clear that there is no easy answer to the question of whether social marketing can or should be applied within the parameters of a participatory approach to development communication. The level of participation will be determined by the organisation responsible for the implementation of the program. It is, however, clear that social marketing could be adapted so that it becomes more participatory and by implication more ethical. Christian organisations opting for the social marketing approach should thus have to be wary of the indicated pitfalls and engage the approach critically. 


\section{List of references}

ANDREASEN, A. 1994. Social marketing: its definition and domain. Journal of public policy and marketing, 13(1):108-114.

BARRANQUERO, A. 2005. From Freire and Habermas to multiplicity: widening the theoretical borders of participative communication for social change. (In Gumucio-Dagron, A. \& Tufte, T., eds. Communication for social change anthology: historical and contemporary readings. South Orange: Communication for Social Change Consortium. p. 920-925.)

BLOOM, P. \& NOVELLI, W. 1981. Problems and challenges of social marketing. Journal of marketing, 45:78-88, Spring.

BRENKERT, G. 2001. The ethics of international social marketing. (In Andreasen, A., ed. Ethics in social marketing. Washington: Georgetown University Press. p. 39-69.)

BRENKERT, G. 2002. Ethical challenges of social marketing. Journal of public policy and marketing, 21(1):14-25.

BROWN, K. 2006. Defining the product in a social marketing effort. Health promotion practice, (7):384-387.

CLEAVER, F. 2001. Institutions, agency and the limitations of participatory approaches to development. (In Gumucio-Dagron, A. \& Tufte, T., eds. Communication for social change anthology: historical and contemporary readings. South Orange: Communication for Change Social Consortium. p. 786-800.)

CORTĖS, C. 1997. Communication at the pace of the pendulum: a half-century in quest of development. (In Gumucio-Dagron, A. \& Tufte, T., eds. Communication for social change anthology: historical and contemporary readings. South Orange: Communication for Change Social Consortium. p. 578-585.)

DOMEGAN, C. 2008. Social marketing: implications for contemporary marketing practices classification scheme. Journal of business \& industrial marketing, 23(2):135-141.

DUHAIME, C., MCTAVISH, R. \& ROSS, C. 1985. Social marketing: an approach to Third World development. Journal of macromarketing, 5:3-13. Spring.

FOX, K. \& KOTLER, P. 1980. The marketing of social causes: the first 10 years. Journal of marketing , 44:24-33, Fall.

FRASER, C. \& RESTREPO-ESTRADE, S. 1988. Why communication? (In Gumucio-Dagron, A. \& Tufte, T., eds. Communication for social change anthology: historical and contemporary readings. South Orange: Communication for Change Social Consortium. p. 572-578.)

FREIRE, P. 1970. Pedagogy of the oppressed. (In Gumucio-Dagron, A. \& Tufte, T., eds. Communication for social change anthology: historical and contemporary readings. South Orange: Communication for Change Social Consortium. p. 44-48.)

GLENANE-ANTONIADIS, A., WHITEWELL, G., BELL, S. \& MENGUC, B. 2003. Extending the vision of social marketing through social capital theory: marketing in the context of information exchange and market failure. Marketing theory, 3(3):323-343. 
GRUNIG, J.E. \& HON, L. 1999. Guidelines for measuring relationships in public relations. Paper presented at the Institute for Public Relations Commission on PR measurement and evaluation, Gainesville, Florida. http://www. instituteforpr.com/measeval/rel_p1.htm Date of access: 7 Jun. 2005.

HASTINGS, G. \& SAREN, M. 2003. The critical contribution of social marketing: theory and application. Marketing theory, (3):305-322.

HUESCA, R. 1996. Naming the world to theorizing its relationships: new directions for participative communication for development. (In GumucioDagron, A. \& Tufte, T., eds. Communication for social change anthology: historical and contemporary readings. South Orange: Communication for Change Social Consortium. p. 528-536.)

HUESCA, R. 2002. Participatory approaches to communication for development. (In Gudykunst, W.B. \& Mody, B., eds. Handbook of international and intercultural communication. Thousand Oaks: Sage. p. 499-517.)

JACOBSON, T.L. 2003. Participatory communication for social change: the relevance of theory of communication action. (In Kalbfleisch, P.J., ed. Communication yearbook 27. Mahwah: Erlbaum. p. 87-123.)

KELLY, J., EDWARDS, R., COMELLO, M., PLESTED, B., THURMAN, P. \& SLATER, M. 2003. The community readiness model: a complementary approach to social marketing. Marketing theory, 3(4):411-426.

KOTLER, P. \& LEE, N. 2008. Social marketing: influencing behaviors for good. Thousand Oaks: Sage.

KOTLER, P. \& ZALTMAN, G. 1971. Social marketing: an approach to planned social change. Journal of marketing, 35:3-12.

LERNER, D. 1964. The passing of traditional society: modernizing the Middle East. New York: Free Press.

MACFADYEN, L., STEAD, M. \& HASTINGS, G. 1999. A synopses of social marketing. www.ism.stir.ac.uk/pdf_docs/social_marketing.pdf. Date of access: 30 Jun. 2008.

MELKOTE, S. 2002. Theories of development communication. (In Gudykunst, W.B. \& Mody, B., eds. Handbook of international and intercultural communication. Thousand Oaks: Sage. p. 419-436.)

MELKOTE, S.R. 2004. Providing care to persons with leprosy: implications for participatory communication. Paper presented at the International Association for Media and Communication Research, Participatory Research Section, Porto Alegre, Brazil, 25-30 July 2004.

PEATTIE, S. \& PEATTIE, K. 2003. Ready to fly solo? Social marketing's dependence on commercial marketing theory. Marketing theory, 3:365385.

RAYNER, M. 2007. Social marketing: how might this contribute to tackling obesity? Obesity reviews, 8(1):195-199.

ROGERS, E.M. \& SINGHAL, A, 2003. Empowerment and communication: lessons learned from organizing for social change. (In Kalbfleisch, P.J., ed. Communication yearbook. Mahwah: Erlbaum. p. 67-85.)

SCHRAMM, W. 1954. Mass media and national development: the role of information in the developing countries. Stanford: Stanford University Press.

SERVAES, J. 1999. Communication for development: one world, multiple cultures. Cresskill: Hampton. 
SIMPLYBIBLE.COM. 2009. Positive Christian communication. http://members. datafast.net.au/sggram/f047.htm Date of access: 27 Feb. 2009.

SMITH, W. 2001. Ethics and the social marketer: a framework for practitioners. (In Andreasen, A., ed. Ethics in social marketing. Washington: Georgetown University Press. p. 1-16.)

SMITH, W.A. 2006. Social marketing: an overview of approach and effects. Injury prevention, 12(1):i38-i43.

SNYDER, L. 2002. Development communication campaigns. (In Gudykunst, W.B. \& Mody, B., eds. Handbook of international and intercultural communication. Thousand Oaks: Sage. p. 457-478.)

SNYMAN, P.G. 1983. Die etiese deontiek van propaganda: wetenskapsteoreties en antropologies benader. (Ongepubliseerde proefskrif.)

SNYMAN, P.G. 1994. Media ethics: a deontological approach. Ecquid novi, 15(1):43-70.

STEAD, M., HASTINGS, G. \& MCDERMOTT, L. 2007. The meaning, effectiveness and future of social marketing. Obesity reviews, 8(1):189193.

THOMAS, P. 1994. Participatory development communication: philosophical premises. (In White, S., Nair, K. \& Ascroft, J., eds. Participatory communication: working for change and development. New Delhi: Sage. p. 4959.)

VEENSTRA, C. 1994. A Christian view on the ethics of journalism. Equid novi, WACC $15(1): 71-85$

see WORLD ASSOCIATION OF CHRISTIAN COMMUNICATORS

WAISBORD, S. 2001. Family tree of theories, methodologies and strategies in development communication. http://www.communicationforsocialchange. org/publications-resources.php?id=105 Date of access: 25 Jun. 2008.

WORLD ASSOCIATION OF CHRISTIAN COMMUNICATORS. 2009. Christian principles of communication. http://www.waccglobal.org/lang-en/aboutwacc/principles.html Date of access: 27 Feb. 2009.

\section{Key concepts:}

Biblical principles of communication

development communication

non-profit sector

participatory approach

social marketing

\section{Kernbegrippe:}

Bybelse perspektiewe op kommunikasie deelnemende benadering nie-winsgewende sektor ontwikkelingskommunikasie sosiale bemarking 
